Western North American Naturalist 67(4), (C) 2007, pp. 601-604

\title{
NEW DISTRIBUTION RECORDS FOR THE QUERÉTERO DUSKY RATTLESNAKE CROTALUS AQUILUS (VIPERIDAE), WITH COMMENTS ON MORPHOLOGY AND HABITAT USE
}

\author{
Jesse M. Meikํㅡ, Estrella Mociño Deloya², and Kirk Setser ${ }^{2}$
}

\begin{abstract}
We provide the 1st documented accounts of the Mexican endemic rattlesnake Crotalus aquilus from the state of México. The new records extend the known distribution of the species into a region where it may be sympatric with the superficially similar $C$. triseriatus. Because these taxa have previously been subject to some taxonomic confusion, we performed a preliminary morphological comparison using individuals of both species obtained from proximal localities. Our analyses support the supposition that these taxa are morphologically distinct. The new localities for $C$. aquilus are situated in high valleys that have been extensively modified by human settlement and agriculture.
\end{abstract}

Key words: Crotalus aquilus, Crotalus triseriatus, rattlesnakes, Mexico, state of México, distribution.

Although Mexico is the center of diversity for rattlesnakes (Crotalus and Sistrurus), basic information regarding natural history, ecology, taxonomy, and distribution remains fragmentary for most species, particularly those endemic to Mexico (Armstrong and Murphy 1979, Campbell and Lamar 2004). Here we report new distribution records for the Querétero dusky rattlesnake (Crotalus aquilus) from the Mexican state of México, a state from which no previous records exist. In addition, we provide data on morphology and habitat use for these newly discovered populations. Throughout this paper we refer to the state of México by including an accent over the "e" and to the country of Mexico by excluding the accent.

Crotalus aquilus is a relatively small, stoutbodied rattlesnake of the $C$. triseriatus group (sensu Murphy et al. 2002), notable for its highly variable ground color and dorsal pattern. Prior to the morphological study of Dorcas (1992), C. aquilus was generally considered a subspecies of $C$. triseriatus. Results from recent molecular studies (e.g., Murphy et al. 2002, Castoe and Parkinson 2006) showed that C. triseriatus remains paraphyletic with respect to both C. lepidus and C. aquilus, suggesting that the taxonomy of this clade needs further revision. Crotalus aquilus is endemic to the highlands north of the Transverse Volcanic Cordillera (southern Mexican Plateau) and has been reported from the Mexican states of Veracruz, San Luis Potosí, Hidalgo, Querétero,
Guanajuato, Jalisco, and Michoacán. The distribution of $C$. triseriatus is a narrow east-west band comprising the high mountains of the Transverse Volcanic Cordillera south of the range of C. aquilus. (Distributions of both species are summarized in Campbell and Lamar 2004.) These authors note that there are no known regions of sympatry between C. aquilus and either C. lepidus or C. triseriatus, although C. triseriatus and C. aquilus occur in close proximity in northern Michoacán (Klauber 1997).

While conducting fieldwork during June and July 2006, we found Crotalus aquilus at 2 localities in the state of México: an agricultural region near San Pedro de los Metates, Municipality of Acambay $\left(19.902^{\circ} \mathrm{N} 99.883^{\circ} \mathrm{W}, 2512\right.$ $\mathrm{m}$; hereafter referred to as "Acambay"), and the northern outskirts of the city of Atlacomulco, Municipality of Atlacomulco $\left(19.831^{\circ} \mathrm{N}\right.$ $\left.99.870^{\circ} \mathrm{W}, 2627 \mathrm{~m}\right)$. We deposited 2 voucher specimens obtained from Acambay in the Museo de Zoología of the Facultad de Ciencias, Universidad Nacional Autónoma de México (MZFC 19258-9), and a digital photograph of the specimen from Atlacomulco in the Amphibian and Reptile Diversity Research Center of the University of Texas at Arlington (UTA 1008). These vouchers represent the 1st documented occurrence of the species in México.

We collected data on morphometrics, scalation, and color pattern from a single male specimen from Atlacomulco and 37 specimens from

1Department of Biology, University of Texas at Arlington, Arlington, TX 76019. E-mail: jmeik@uta.edu

${ }^{2}$ Departmento de Biología Animal y Ecología, Campus Universitario de Fuentenueva, Universidad de Granada, Granada 18071, España. 
TABLE 1. Range and modal values for meristic characters recorded from male and female Crotalus aquilus from México, Mexico. Asterisks denote characters that exhibited significant sexual dimorphism (MANOVA post hoc comparisons, $\alpha=$ $0.05)$.

\begin{tabular}{lcccc}
\hline & \multicolumn{2}{c}{ Females } & \multicolumn{2}{c}{ Males } \\
\cline { 2 - 4 } & Range & Mode & Range & Mode \\
\hline Dorsal body blotches & $24-35$ & 32 & $26-32$ & 29 \\
Tail bands* & $2-4$ & 3 & $4-6$ & 5 \\
Rattle fringe scales & $8-10$ & 10 & $23-28$ & 10 \\
Subcaudals* & $18-24$ & 22 & $136-144$ & 141 \\
Ventrals* & $141-150$ & 14.5 & $10-13$ & 12 \\
Supralabials & $11-13$ & 12 & $10-12$ & 12 \\
Infralabials & $11-12$ & 22 & $20-26$ & 22 \\
Interrictals & $20-25$ & 23 & $21-23$ & 23 \\
Midbody dorsal scale rows & $21-24$ & 3 & $2-3$ & 3 \\
Intersupraoculars & 3 & & & 23 \\
\hline
\end{tabular}

Acambay (17 females, 20 males). In addition we compared these data to those collected from specimens of the superficially similar $C$. triseriatus (4 females, 2 males) obtained from 2 nearby localities (see below). We anesthetized rattlesnakes with isoflurane prior to data collection. Snakes were later released at their point of capture. Meristic data were collected only from postneonatal individuals. We evaluated color pattern variation by comparing digital photographs. We investigated sexual differences in meristic characters of C. aquilus using multivariate analysis of variance (MANOVA), and in postneonatal snout-vent length (SVL) using a $t$ test assuming unequal variances. We further evaluated morphological variation between $C$. aquilus $(n=23)$ and $C$. triseriatus $(n=6)$ using principal component analysis (PCA) applied to the correlation matrix, which was derived from 10 characters: (1) number of rattle fringe scales, (2) ln-transformed proximal rattle segment width, (3) ln-transformed body length, (4) ln-transformed head length, (5) ln-transformed tail length, (6) number of subcaudal scales, (7) ln-transformed head width, (8) number of tail bands, (9) number of primary body blotches, and (10) number of ventral scales. Body length was obtained by subtracting head length from SVL. All statistical analyses were performed using SYSTAT 11.0 (SPSS, Inc., Chicago, IL).

Morphological data agreed with previously published accounts (Dorcas 1992, Campbell and Lamar 2004). On average, postneonatal males were larger in SVL than postneonatal females $\left(n=11\right.$ females and 17 males, $\bar{x}_{\text {males }}$ $=532 \pm 17 \mathrm{~mm}, \bar{x}_{\text {females }}=433 \pm 19 \mathrm{~mm}: t=$ $-3.96, \mathrm{df}=23, P=0.0006$ ). Males had higher subcaudal scale counts, more tail bands, and lower ventral scale counts than females, as is typical of rattlesnakes (Klauber 1997; meristic characters are summarized in Table 1). The results of PCA provided further resolution in describing patterns of morphological variation (Fig. 1). We interpreted only the 1st and 2nd principal component axes, which accounted for $50.2 \%$ and $24.5 \%$ of the total variance in the dataset, respectively. Scatterplots of individual factor scores for C. aquilus and C. triseriatus revealed that variation in the 1st axis was structured primarily by sexual dimorphism, which demonstrated a similar pattern for both species: males of both species were larger in all morphometric characters and had higher subcaudal scale counts than females. Variation in the 2nd axis was structured by morphological disparity between the 2 species: C. aquilus had more rattle fringe scales, greater proximal rattle segment width, fewer subcaudals, a narrower head, and fewer tail bands and body blotches than $C$. triseriatus. These results are notable in that, with the exception of a single C. triseriatus, all specimens used in the analysis originated within $25 \mathrm{~km}$ of each other, supporting the assertion that intergradation likely does not occur between C. aquilus and C. triseriatus (see Gloyd 1940, Duellman 1961, Klauber 1997).

Individuals of C. aquilus from populations in México were similar in coloration and pattern to individuals from more northern populations. Most males were pale green in ground color with chocolate or mauve-colored blotches. Females ranged from gray-green to pale brown in ground color with brown blotches. Females generally were noticeably duller than males. 

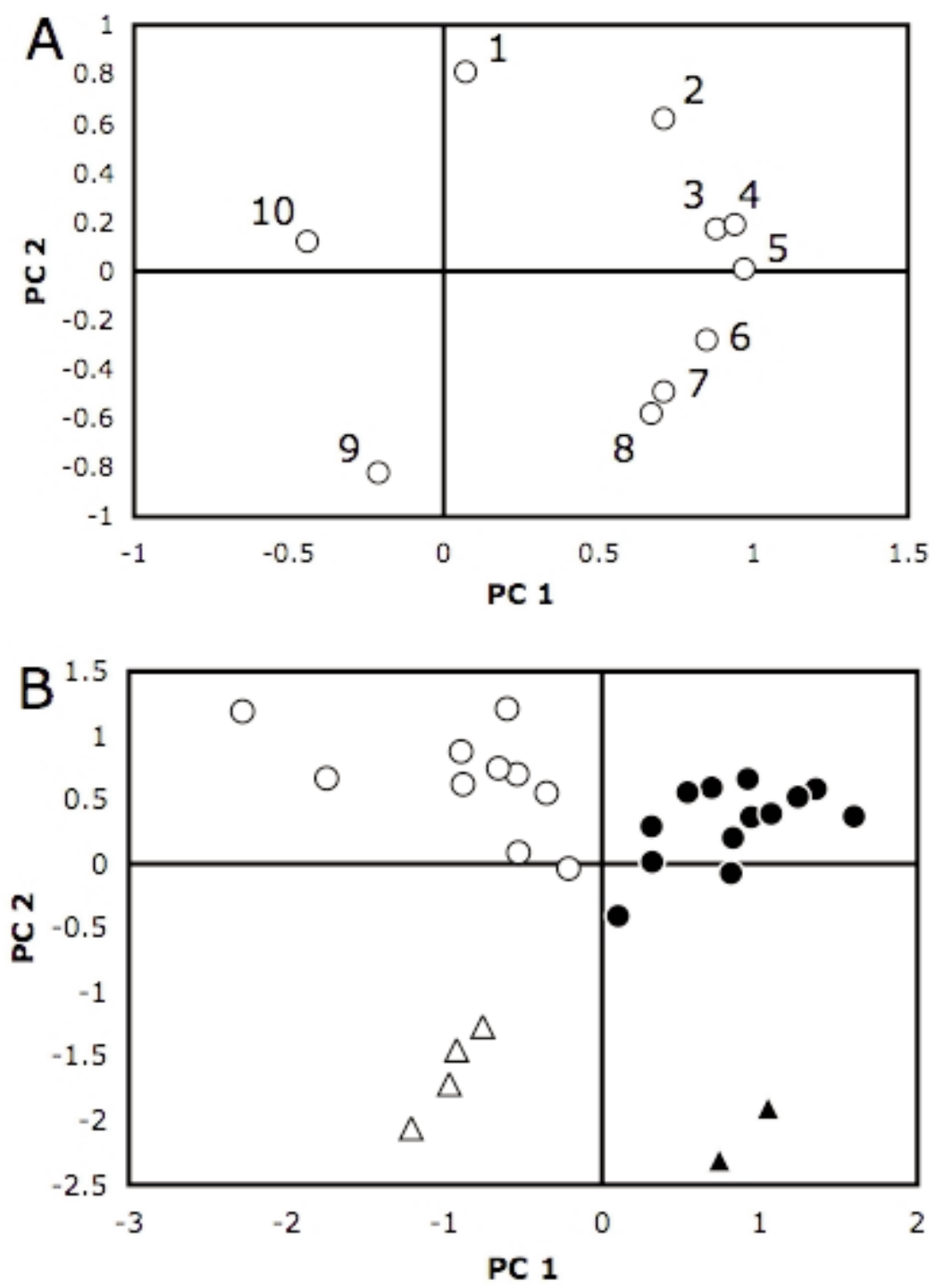

Fig. 1. Results of principal component analysis of morphological characters for Crotalus aquilus and C. triseriatus from México, Mexico. A, Plot of factor loadings showing relative influence and correlations of individual characters on the first 2 principal component axes. Numbers correspond to the character identifications provided in the text. B, Scatterplot of individual factor scores along the first 2 principal component axes. Open circles $=$ C. aquilus females; filled circles $=$ C. aquilus males; open triangles $=C$. triseriatus females; filled triangles $=C$. triseriatus males.

Most C. aquilus that we examined had paired nape and parietal blotches, although parietal blotches were sometimes absent. A few specimens possessed an additional pair of blotches immediately posterior to the supraoculars. The primary dorsal blotches were usually longer than wide and roughly rectangular, or they were constricted longitudinally into $\mathrm{H}$-shaped markings. In most specimens, dorsal blotches were distinct; however, considerable interindividual variation exists, and occasionally the ground color and blotch color were so similar that blotches were barely discernible.

Campbell and Lamar (2004) reported that C. aquilus was previously abundant in cultivated agave fields near La Estanzuela, Hidalgo. Our observations further document C. aquilus in habitats altered by agriculture. Both of the 
new C. aquilus localities from México are situated in valleys or foothills that have been almost entirely converted into cropland, pastures, and human settlements. Crotalus aquilus appears to tolerate at least some level of agricultural activity, and certain agricultural practices may allow populations of this species to persist in human-modified habitats. For example, near Acambay we found C. aquilus associated with small rock piles immediately adjacent to cornfields; these piles were created by farmers clearing stones from croplands. The specimen from Atlacomulco was found in a similar rock pile. Near Acambay, C. aquilus also used earthen canal berms, where individuals were found in dense vegetation (e.g., bunchgrass, reeds, etc.). Rattlesnakes were also frequently encountered coiled on or near small cement canals. When disturbed, some of these snakes sought refuge within the numerous cavities and crevices afforded by the decaying cement canal banks. Although expanses of corn monocultures likely do not provide suitable habitat for rattlesnakes, we infrequently observed individuals in the narrow, grassy strips between crops and in fallow fields. We documented utilization of some agricultural areas by C. aquilus, but the long-term sustainability of populations under such conditions remains unknown, and we do not suggest that this species can tolerate intensive agricultural practices.

With the addition of C. aquilus, 6 species of rattlesnake are known from the state of México. The new records presented here extend the known distribution of $C$. aquilus south to the point of potential geographic overlap with the closely related $C$. triseriatus. We collected C. triseriatus from 2 localities in northern México in the vicinity of Atlacomulco: San Jose del Rincón $\left(19.666^{\circ} \mathrm{N}, 100.208^{\circ} \mathrm{W}, 3084 \mathrm{~m}\right.$; UTA 1009 [digital image collection]), approximately $50 \mathrm{~km}$ (air line) west of Atlacomulco, and near Jocotitlan $\left(19.720^{\circ} \mathrm{N}, 99.782^{\circ} \mathrm{W}, 2810 \mathrm{~m}\right.$; UTA 1010-11 [digital image collection]), approximately $15 \mathrm{~km}$ (air line) southeast of Atlacomulco. The records are significant because they represent the most proximate occurrences of $C$. aquilus and C. triseriatus. The southernmost locality for C. aquilus (Atlacomulco) is in the northern foothills of the Toluca Valley, and mountains bordering the Toluca Valley to the east, south, and west harbor populations of $C$. triseriatus. The localities for C. aquilus range in elevation from 2500 to $2600 \mathrm{~m}$ above sea level, whereas the localities for $C$. triseriatus range from 2800 to $3100 \mathrm{~m}$ above sea level. Aside from the possible elevational differences, we are unaware of any geographic or habitat barriers that would preclude contact of these species. Future collecting efforts in this region may identify areas of sympatry between the species or areas of parapatry based on elevational partitioning.

We thank SEMARNAT, and in particular E. Covain and F. Sanchez, for providing necessary permits. The following persons generously provided field assistance: F. Bertoni, E. Cabra, J. Flores, B. Muscher, J. Leon, A. Maldonado, E. Maldonado, D. Rodriquez, and E. Sunila. We also thank A. Kardon, D. Lazcano, C. Setser, and D. Setser for providing logistical assistance, and S. Aird, J. Campbell, and A. Savitzky for reviewing early drafts of this manuscript.

\section{Literature Cited}

ARmstrong, B.L., AND J.B. Murphy. 1979. The natural history of Mexican rattlesnakes. Special Publication of the Museum of Natural History, University of Kansas, No. 5.88 pp.

Campbell, J.A., and W.W. Lamar. 2004. The venomous reptiles of the Western Hemisphere. Cornell University Press, Ithaca, NY. 870 pp.

Castoe, T.A., And C.P. Parkinson. 2006. Bayesian mixed models and the phylogeny of pitvipers (Serpentes: Viperidae). Molecular Phylogenetics and Evolution 39:91-110.

DorCAS, M.E. 1992. Relationships among montane populations of Crotalus lepidus and Crotalus triseriatus. Pages 71-87 in J.A. Campbell and E.D. Brodie, Jr., editors, Biology of the pitvipers. Selva Press, Tyler, TX.

Duellman, W.E. 1961. The amphibians and reptiles of Michoacán, Mexico. Publications of the Museum of Natural History, University of Kansas 15:1-148.

GLOYD, H.K. 1940. The rattlesnakes, genera Sistrurus and Crotalus: a study in zoogeography and evolution. Special Publications of the Chicago Academy of Sciences 4:1-270.

KLAuber, L.M. 1997. Rattlesnakes: their habits, life histories, and influence on mankind. 2nd edition [reprint]. University of California Press, Berkeley. $1580 \mathrm{pp}$.

Murphy, R.W., J. Fu, A. Lathrop, J.V. Feltham, and V. Kovac. 2002. Phylogeny of the rattlesnakes (Crotalus and Sistrurus) inferred from sequences of five mitochondrial DNA genes. Pages 69-92 in G.W. Schuett, M. Höggren, M.E. Douglas, and H.W. Greene, editors, Biology of the vipers. Eagle Mountain Publishing, Eagle Mountain, UT.

Received 22 November 2006 Accepted 2 April 2007 